\title{
Rebounding on the Tenure Track: Carving Out a Place of Your Own in the Academy
}

Valeria Sinclair-Chapman, Purdue University

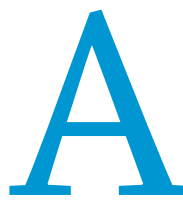

$s$ I sat down to write this piece, I was surprised to find myself seeking distance from my subject. I wrestled with the framing. It had taken me nearly a decade to discover a language of personal loss that could be accessed in public spaces, shared with select audiences, and translated for academic use. ${ }^{1}$ This paper reflects a desire to bring my whole self to this enterprise, along with a determination not to open myself up to more abuse-neither from those who see themselves as gatekeepers of a discipline that is in the midst of a slow transition, nor from the academy itself, which opens and closes its doors like flaps over the blades of an industrial fan, alternately beckoning and shredding. I am ever-cognizant that one must be nimble to make it across minefields, reminded that many of us dance across a tightrope. ${ }^{2}$

\section{INTRODUCTION}

Black women have a history of storytelling. It is part of how we position and reposition ourselves in spaces that routinely try to convince us that we are disposable; how we resist and redefine; a vehicle whereby we explore and develop epistemologies built upon centuries of lived experience (Angelou 1969; Collins 1990; hooks 1984; Morrison 1992; Walker 1983). These stories sustain and encourage us. The stories we tell to and about ourselves help us stand our ground and claim a space in the academy. ${ }^{3}$ Our stories are acts of resistance.

This article begins with a framework for understanding the tenure track as a production of academic violence and tenure denial as the marking of individuals with stigma. While most untenured faculty can relate to the idea of "surviving" the tenure track, the notion of academic violence goes beyond merely contending with the uncertainty and demands of seeking tenure. What follows is my story, presented to the best of my recollection, of unexpected failure on a very public stage and then rebounding in an atmosphere of intellectual and demographic inclusion. My narrative is meant to be a cautionary tale built on solidarity rather than fear or scolding. Interventions are often directed at individuals rather than institutions. Did the candidate do enough, sacrifice enough, listen enough? These are all good and relevant questions, but they leave unanswered the responsibility of the department and the college or university to engage in self-reflection and, to the extent possible, not enact harm.

\section{Academic Violence, Scarlet Letters, and Neon Signs}

The academy, particularly historically-white institutions (HWIs), can be a hostile place for aspiring faculty and especially women of color. Scholarship abounds with notions of survival, overcoming, and defeat (Stanley 2006; Turner, Gonzalez, and Wood 2008).4 For academics of all stripes, tenure is the fabled "holy grail," elusive, yet tantalizing and dearly desired (Adams 2007). But, for black women, the academy can be actively hostile, not only dredging up imagery of violence, for example, minefields, isolation, and death, but also of specifically gendered-violence such as rape, physical abuse, and abortion. ${ }^{5}$ The academy imprints black women with violence.

Laura J. Lee and Curtis A. Leonard provide a useful framework for understanding the violence perpetuated against people of color at HWIs. "African American scholars...," they write, "are a group at risk" (Lee and Leonard 2001, 168). The tenure process, dependent as it is on the subjective evaluations of insiders of a relatively powerless outsider, "often becomes the conduit for the emergence of violent behaviors" in the academy. Academic violence, although rarely physical, is predicated on information and power asymmetries that are exacerbated by societal norms of race, and if I may add, gender. It is pervasive and, "inherently perilous to the psychological well-being of African Americans" (Lee and Leonard 2001, 169). Violence occurs in faculty meetings, performance and teaching evaluations, hiring, promotion, and advancement. Such violence isolates black faculty, renders them invisible, undermines ambition, reshapes scholarly goals, and fuels an exodus from higher education (Lee and Leonard 2001; Stanley 2006; Turner et al. 2008).

The very structure of the academy permits academic violence. The tenure process is shaped as much by hierarchy and bureaucracy as it is by decentralization, fickleness, and opacity (Adams 2007). While a candidate's publication record is what counts most in most institutions, it also matters how the department is ranked (or aspires to be ranked), who heads the department, what the dean wants, what the financial situation is like, what has occurred politically in the previous year, and so on. Written and unwritten rules, formal and informal relationships, professional mentoring and advocacy collectively contribute to the alchemy that makes for tenure at one place and denial at another (Alleman, Nelson, and Allen 2017; Lee and Leonard 2001; Matthew 2016; but see Marshall and 
Rothgeb 2011). As Patricia A. Matthew recently observed in the preface to a volume she edited on the unwritten rules of the tenure track, and following her own protracted and ultimately successful tenure battle, "the haphazard nature of these processes are more structurally complicated for faculty almost anywhere, but I already knew, based on my own assessment and that of colleagues whom I trusted, that my case was on the lean side of possible. To be honest, I was banking on promotion without tenure. One person in my department had already been promoted that way nearly a decade earlier,

\section{While a candidate's publication record is what counts most in most institutions, it also matters how the department is ranked (or aspires to be ranked), who heads the department, what the dean wants, what the financial situation is like, what has occurred politically in the previous year, and so on.}

of color than for their white counterparts" (Matthew 2016, xv). She goes on to note:

[F] aculty of color always have to do at least two things at the same time as they go about their work: figure out how to cope with (confront, deflect, or absorb) the daily microagressions of the academy while trying to navigate structural obstacles that everyone faces in environments that are either maddeningly indifferent or hostile.

Granting tenure represents a long-term commitment, potentially across many decades, to an individual scholar and support for their body of scholarship (Adams 2007). Those at the department-level, closest to the faculty member under review, are tasked as the front line in evaluating their untenured colleagues. Typically, this decision is made under the advisement of scholars from outside the department who are trusted arbiters in the discipline, and after the untenured faculty member completes a probationary period of five to 10 years (Adams 2007, 78; Alleman, Nelson, and Allen 2017). ${ }^{6}$ In their working paper on how individuals cope with the aftereffects of being denied tenure, Nathan F. Alleman and his colleagues report that although approximately one in five tenure-eligible-faculty are denied each year (with variation by field, discipline, institutions and other factors), scholarship on negative outcomes of the tenure process is unsystematic and rare (Alleman et al. 2017).

For those who, for whatever reason, misread the tea leaves, go up for tenure and fail, the consequences are devastating. The stigma of tenure denial "raises not only questions of competence and future employability, but also issues of how to navigate one's new and undesirable social and professional identity" (Alleman, Nelson, and Allen 2017, 3). Beyond the individual experience, faculty who are denied tenure also must contend with a very public signal that they are no longer (and do not deserve to be) upstanding members of the academy. This crisis of legitimacy is akin to wearing a scarlet letter that periodically lights up like a flashing neon sign while a tin-cup robot wanders aimlessly about yelling "Danger, Will Robinson, Danger!" as your foot slips precariously off a cliff.

\section{Facing the Facts of Hard Tenure Cases}

Mine was not an easy case. Admittedly, the requirements for tenure and promotion are fluid and somewhat ambiguous and another in the fairly recent past. I considered not submitting my file, but, my department chair had practically begged me to go up, pushing aside my concerns with an appeal to "at least let the department make the decision," rather than pull myself out of the running. I heard the request, whether intended or not, as a small reassurance.

As I assembled my documents, I considered the way that my life affected my work and how none of that mattered. Within a month of winning a prestigious fellowship, my mother suffered a stroke. Instead of diving into my project as planned, I spent the next several months nursing her back to health. That same year, I suffered the first of three miscarriages that would occur during the tenure track. These were unbearable, life-altering experiences, completely irrelevant professionally. Life happens, yes, but only outside of the tenure track.

When the chair later informed me that no one in the department felt equipped to evaluate my file and thus they would rely on the letter writers, I once again could not properly decode what I was being told. It felt vaguely like a warning, but of what, exactly? With the benefit of hindsight, I realize that the chair was explaining that I would have few advocates in the room when my file was being discussed. This probably seemed reasonable and fair. Hire someone about whose work you know nothing and then leave that person to sink or swim on the word of six people whom you trust. Perhaps that was a time to ask for a reassessment of the rules, a shifting in the names of letter writers, a re-weighting of the value of various perspectives on my existing body of work. Isolated, alone, and deeply ashamed, I did not know to ask.

To make a long, painful story short: My colleagues voted against both tenure and promotion. I felt humiliated. When a senior colleague offered that the department valued me as a teacher and by implication, not as a scholar, I, being the only black person in the entire building, was offended. I cursed. It was unprofessional and I do not advise it. But, it was an honest rejection of a peace offering in the wake of an assault. At the same time that the department informed me of the negative tenure and promotion decisions, it also offered to keep me on staff as an instructor, a senior lecturer to be more precise. My senior colleague suggested that I think about it before I made a decision to reject the offer out of hand, a reprieve for which I am grateful to this day. In the ensuing weeks over break, 
I played Public Enemy's "Fight the Power," loud from my office and displayed the poem, "If We Must Die," by Claude McKay alongside the old standbys on my office bulletin board: Audre Lorde's, "A Litany for Survival," and Maya Angelou's "Our Grandmothers." With poetry, I reminded myself that, "No one, no, nor no one million ones dare deny me God" (emphasis added).7 I gathered myself together, went regularly to the department, stopped all formal interactions with my former colleagues, connected more freely with colleagues across campus, and negotiated a new pathway forward. I was battered, but still standing. My relationship with the department was forever changed. visible, silenced, and vulnerable. I was black, but not a man, in a place where women's power was mostly not a thing and where not a single black woman had successfully completed the tenure process (from new assistant professor to associate professor) in the College of Arts and Sciences in the more than 150 years since the institution's founding. ${ }^{.} \mathrm{A}$ senior colleague who refused to speak to me as we passed in the halls, openly mocked me in front of graduate students, and once, during a dissertation defense where I was present as a committee member, asked a graduate student whether there was any need in the discipline for my subfield. Dumbstruck, I responded weakly, "Yes, because I need a job." This colleague

\section{Academic violence rarely plays out in a direct assault; instead, it is executed in the seams, around the margins, like a wooden paddle against the soles of the feet that will leave a sting, but not a mark.}

Academic violence rarely plays out in a direct assault; instead, it is executed in the seams, around the margins, like a wooden paddle against the soles of the feet that will leave a sting, but not a mark. It also need not be intentional. In my own experience, the many ways that I was reminded that I did not belong were so casual that I cannot believe they were informed by intent. Mistakes were amplified. Transgressions were unspoken, but unforgiven. My ideas were taken up by others while my contributions were conveniently forgotten. This was all before I came up for tenure. After the denial, the nature of the indignities simply shifted. Now, I was no longer greeted in the hall by graduate students. I was reminded by a colleague "how we do things around here" even though I had actually been in the department longer. I was informed days before the start of the semester that I would no longer be assigned teaching assistants in a course for which I had typically had two or three. I was making major contributions in other areas of my professional life, namely as an administrator, but in my home department I was being erased in front of my own eyes.

\section{GOODNESS OF FIT}

As they say, hindsight is 20-20. I now realize that good fit is a two-way street. When you get denied, you hear over and over again about how you were not a good fit for the place that has voted you off the island. It is equally as likely, however, that the place that you were was also not a good fit for you. This small fact is hard to see when all the longing and desire seems to work in one direction-when the holy grail is theirs and not yours. But, taking my first job was not an easy decision. I had options that were closer to home, closer to family, to people that I cared about and who knew and cared about me. The job that I took was in a top-ranked, sink or swim department. It was a perfectly good place to work and for some people, it would have been a dream job. In fact, one of my dissertation advisers told me pointedly, "taking this job is a no-brainer."

I landed in a place where power was unapologetically white, male, and wealthy. I felt both bigger and smaller, alone, presented my tenure case. I suppose that he was the "hard sale," and thus the one to be convinced. Plainly, he was not. As I consider it now, my previous institution was simply not a good fit.

\section{“Luke, I am your father!”}

Long, long ago, in a galaxy far away, I was a bright-eyed, brand new faculty member, young and brilliant, not unlike some of you. I worked with talented people, trained some brilliant scholars, and learned how to navigate in an elite white space. I also encountered roadblocks. Some of the roadblocks relate to sheer numbers. Women and men earn doctorates at about the same rate, but the academic ranks remain disproportionately male (Schuster and Finkelstein 2006 and disproportionately white (Katz and Belo-Osage 2016, 13), particularly in full time and leadership positions. ${ }^{9}$ At HWIs, challenging institutional conditions such as the absence of role models or intellectual community, or the weight of hostile climates are often unrecognized or discounted by department and college leadership.

Faculty of color are asked to provide a rationale for attending conferences where the experiences of people of color are centered, in addition to the major conferences in their disciplines. ${ }^{10}$ The time we spend in African American, Latino, Asian American, or Women's and Gender Studies is questioned as a preference-and often viewed as a distractionrather than recognized as key to intellectual development and soul-saving (Few-Demo et al. 2016). ${ }^{11}$ My experiences are not universal, but the experiences of others and the numbers suggest that some of you will find yourselves in similar circumstances. In that way, I just might be the father you never knew you had.

\section{The French's Mustard Years}

A 1980 os French's mustard commercial features a little boy spreading mustard on a sandwich, singing: "You are my sunshine, my only sunshine. You make me happy when skies are gray. You'll never know just how much I love you. Please don't 
take my sunshine away." This sentiment sums up the way I feel about my current department, my colleagues, my students, and my professional life: sunshine. In 2013, I accepted a job offer from the Department of Political Science at Purdue University. Coming off the denial at my previous institution, I was pretty broken. I had given talks during my terminal year, but not especially good ones. I lacked confidence. Years later, my visit to Purdue exceeded my expectations. I liked the people and the department, and they seemed to like me back. Two years after I arrived, I was tenured.

My work and the questions that interest me found synergies with colleagues in other subfields and departments. I felt at home in my department. A broad and inclusive intellectual community emerged. The department had a multi-layered mentoring program for junior faculty, and every year, faculty are reviewed in a fashion that signals progress toward tenure or promotion (see Alex-Assensoh et al. 2005). ${ }^{12}$ My colleagues at Purdue valued the work that I do on race and politics and viewed my record as tenurable. Thus began what I call my French's mustard years. Most days, I look forward to going to work. I enjoy getting together with my colleagues for dinner or drinks. I suspect that this state of affairs is routine for someone who has a sense of belonging at the place where they work, for those who laugh and speak without mentally checking to see if what they just said or did is okay.

At my previous institution, I found myself to be on a constant, unending audition, always one step away from what could be a fatal error. A good fit works both ways (see, Alexander-Floyd 2015). For me, a good fit is a place where I feel welcomed and wanted, not always on guard. My contributions are valued. I am part of a community built around norms of responsibility and reciprocity with expectations of respect and inclusion. My current department could teach the discipline how to create a realistic and sustainable model for diversity and inclusion. ${ }^{13}$

\section{A WORD TO THE WISE}

As I conclude, I would like to offer a few nuggets of advice to graduate students and junior faculty. Do not easily concede to the academy or the discipline's two-mindedness about whether you belong (see Few-Demo et al. 2016). If you want to stay, you should do your darndest to do so. Write first, then talk. See your thoughts in print. Such is the currency of the academic enterprise, the "coin of the realm." Resist the urge to retreat or retire into the shadows when the violence comes. Recognize it for what it is-an attempt to assert and maintain the status quo. Recognize the ability to marshal discomfort as your superpower.

Remember that you work with your colleagues, but not for them. Your papers and presentations operate as your assembly line. Keep 'em coming down the line; nothing gets put back on the shelf. Send it out, share it, present it, revise it, and send it out again-until it lands (see Walker 2019, this issue). Nurture a robust set of advisers and avail yourself of support. It is nearly impossible to navigate this arena alone. Find your way to communities that sustain you. Some will think that doing so is a distraction, but you already know that community is one of the things that makes it possible for you to do your work.
To department chairs and others who wish to recruit and retain faculty of color I offer the following guideposts (see also Sinclair-Chapman 2015):

1. No one should be surprised to be denied promotion or tenure. If a tenure candidate is surprised by a negative decision, then something is amiss in the process.

2. When departments fail to promote or tenure one of their faculty colleagues, the responsibility for failure is a shared one. This signals an opportunity for departmental self-reflection and accountability.

3. Disciplines must also be held to account for what they do and allow to happen to the people they train, especially those who are marginalized by subfield, research focus, or demographic differences that place them outside of the modal categories that are historically enshrined and normalized. The major disciplinary associations should conduct a longitudinal analysis examining whether there are patterns in tenure denials and, if those denied tenure remain in academia, where they land. Disparities in gender, race and ethnicity should be identified and addressed.

\section{ACKNOWLEDGMENTS}

I wish to thank the organizers and participants of the Women of Color in Political Science (WCPS) 2017 Workshop, a pre-conference for the annual meeting of the American Political Science Association held August 30, 2017. I also wish to thank the participants of the annual faculty of color conference at the University of North Texas, "Intersectionalities in the Ivory Tower," held April 13, 2018. I am indebted to Sasha Eloi-Evans for her keen eye, to Frank Baumgartner, Rosalee Clawson, Michael Minta, and Laurel Weldon for their thoughtful comments, and to former colleagues who offered their insights and useful corrections. All errors are my own..

\section{NOTES}

1. In late summer 2017 , I delivered a plenary talk entitled "Yes It Can Happen to You" at the Women of Color in Political Science (WCPS) pre-conference ahead of the annual meeting of the APSA. This was my first public discussion of being denied tenure and a host of other challenges with which I contended during my first academic appointment. In addition to the word of caution in the title, I added, "and You Can Live to Tell About It," as a signal of the resilience that is required for women of color to persist and thrive in the academy.

2. The image that comes to mind is that of actor-singer Janelle Monae and the video for her song, "Tightrope," which can be found here: https://www. youtube.com/watch?v=pwnefUaKCbc. When I gave the talk, I actually did my own, not nearly as impressive, version of "tipping on the tightrope."

3. Consider for instance, the various iterations of the "Black Women in the Ivory Tower" conference and those with similar themes.

4. Scanning the table of contents of the path-breaking edited volume, Presumed Incompetent (Gutierrez et al. 2012), which offers an examination of the experiences of women of color in the academy, is indicative of the widespread experience of violence enacted upon and trauma experienced by women of color. Descriptors in the chapter titles include: facing down, prostitute, servant, elusive belonging, violence, burden, striving, and even a reference to the "silence of the lambs" of horror movie fame. Nirmal Puwar (2004a, 72) likewise provides insight into why women and women of color in particular often experience violence and trauma in the academy, writing that they are often, literally, "space invaders," who invade spaces traditionally reserved for white men, and come to represent "territorial threat, invoking metaphors of war, battle, and invasion."

5. This may seem hyperbolic, but these words reflect my immediate interpretation of my own experience. I felt vulnerable, routinely assaulted, attacked and ultimately aborted, unwillingly shed from the body of the 
department where I worked. It is a traumatic experience and generic phrases such as "hostile workplace" or "chilly climate" are insufficient.

6. In my own experience, the process of identifying potential outside reviewers also becomes tricky for faculty of color, and more so for women of color. It matters whether the tenure track faculty member and her scholarship is valued by and legible to her department colleagues. When it is, senior [white] faculty can more easily identify appropriate reviewers. When it is not, senior faculty may rely more heavily or solely on outside letter writers who may or may not be appropriate. Tenure track faculty of color may end up with a set of reviewers with whom they are only distantly or superficially connected. The advisers from whom faculty of color regularly seek counsel may likewise be only distantly known, if recognized at all, by the senior white colleagues. Under such circumstances, tenured faculty may seek one or more gatekeepers to tell them whether their untenured colleague has demonstrated herself worthy of all of the risks and expense of tenure (Katz and Bello-Osage 2016, 12).

7. Maya Angelou, "Our Grandmothers."

8. In 2018, the College promoted and tenured an African American woman from new assistant to associate professor for the first time in its nearly 200 year history. As evidence, in part, to the inhospitable climate, she is leaving to take a job elsewhere despite marking this historic milestone. Other African American women have entered with tenure or been offered tenure after arriving at the College from first jobs held elsewhere. The expected protections of tenure have not worked in favor of black women at this institution. With one exception, every black woman in the College who earned tenure or promotion has left for greener pastures. This fact points to a broader context where role models, leadership, and resources from people of color, and especially women of color, was quite scarce. As one friend suggested to me years ago when she declined a tenure track job offer from a small liberal arts education department where she would have been their first black woman hire, "they would need to offer me hazard pay." In other words, departments are not the only ones taking a risk when they hire outside of their norm. The new hire is also taking a risk.

9. The APSA Committee on the Status of Women in the Profession reports in "Pipeline to Tenure," that nearly $87 \%$ of female faculty are white (Katz and Belo-Osage 2016, 13).

10. Specialized conferences in political science include the National Conference of Black Political Scientists, which is celebrating its 5oth anniversary in 2019, and the Western Political Science Association, which boasts a broad attendance and an inclusive focus on Latino and Asian American politics.

11. Few-Demo's coauthors are two administrators from her home institution with decision-making authority over her tenure case. In the chapter, she describes how she enlists her senior colleagues to write about their divergent views on her scholarly contributions and academic priorities. The chapter includes perspectives on what each of them learned about each other and about the experiences of a faculty of color in the process of writing.

12. Yvette M. Alex-Assensoh and her colleagues noted that departments can help lessen what I call academic violence against faculty of color by providing "[a] support system which includes a formal mentoring program [and] a hospitable environment and 'opportunity structure' for professiona development and advancement" $(2005,283)$.

13. During my time at Purdue University, the political science department has had not one or two, but as many as five, African American faculty at the same time. Given the underrepresentation of African Americans in the discipline, this is a rare event. It is relevant because "the lack of faculty diversity is not only an issue of recruitment, but also of retention" (AlexAssensoh et al. 2005, 283, see also Alexander-Floyd 2015).

\section{REF ERENCES}

Adams, Mark L. 2007. "The Quest for Tenure: Job Security and Academic Freedom." Catholic University Law Review 56 (1): 67-98.
Alexander-Floyd, Nikol G. 2015. "Women of Color, Space Invaders, and Political Science: Practical Strategies for Transforming Institutional Practices." PS: Politics \& Political Science 48 (3): 464-68.

Alex-Assensoh, Yvette, Terri Givens, Kathie Golden, Vincent L. Hutchings, Sherri L. Wallace, and Kenny J. Whitby. 2005. "Mentoring and AfricanAmerican Political Scientists.” PS: Political Science \& Politics 38 (2): $283-85$.

Alleman, Nathan F., Justin J. Nelson, and Cara Cliburn Allen. 2017. “The Stigma of Tenure Denied." Paper presented at the annual meeting of the Association for the Study of Higher Education (ASHE), Houston, Texas, November 2017

Angelou, Maya. 1969. I Know Why the Caged Bird Sings. New York: Random House.

Angelou, Maya. 1991. "Our Grandmothers," in I Shall Not Be Moved. New York: Random House.

Collins, Patricia Hill. 1990. Black Feminist Thought: Knowledge, Consciousness, and the Politics of Empowerment. NY: Routledge.

Few-Demo, April L., Fred P. Piercy, and Andrew J. Stremmel. 2016. "One Professional's Story from Three Perspectives," in Patricia A. Matthews (ed.) Written/Unwritten: Diversity and the Hidden Truths of Tenure. Chapel Hill: University of North Carolina Press.

Gutierrez y Muhs, Gabriella, Yolanda Flores Niemann, Carmen G. Gonzalez, and Angela P. Harris. (Eds.) 2012. Presumed Incompetent: The Intersections of Race and Class for Women in Academia. Logan, UT: Utah State University Press.

hooks, bell. 1984. Feminist Theory: From Margin to Center. 2nd ed. Cambridge, MA: South End Press.

Katz, Andrea and Ameze Belo-Osage. 2016. "Pipeline to Tenure: Institutional Practices for Hiring, Mentoring, and Advancing Women in Academia." Prepared by the APSA Committee for the Status of Women in the Profession, May 12, 2016.

Lee, Laura J. and Curtis A. Leonard. 2001. "Violence in Predominantly White Institutions of Higher Education." Journal of Human Behavior in the Social Environment 4: 167-86.

Marshall, Bryan W. and John M. Rothgeb, Jr. 2011. "So You Want Tenure? Factors Affecting Tenure Decisions in Political Science Departments." PS: Political Science \& Politics 43 (3): 571-77.

Matthew, Patricia A. (ed). 2016. Written/Unwritten: Diversity and the Hidden Truths of Tenure. Chapel Hill: University of North Carolina Press.

Morrison, Toni. 1992. Playing in the Dark: Whiteness and the Literary Imagination. New York, NY: Vintage Press

Puwar, Nirmal. 2004a. “Thinking About Making a Difference.” British Journal of Politics and International Relations 6 (1): 65-80.

Schuster, Jack H. and Martin J. Finkelstein. 2006. The American Faculty: The Restructuring of Academic Work and Careers. Baltimore: Johns Hopkins University Press.

Sinclair-Chapman, Valeria. 2015. "Leveraging Diversity in Political Science for Institutional and Disciplinary Change." PS: Political Science \& Politics $48(3): 454-58$.

Stanley, Christine A. 2006. "Coloring the Academic Landscape: Faculty of Color Breaking the Silence in Predominantly White Colleges and Universities." American Educational Research Journal 43 (4): 701-736.

Turner, Caroline Sotello Viernes, Juan Carlos Gonzalez, and J. Luke Wood. 2008. "Faculty of Color in Academe: What 20 Years of Literature Tells Us." Journal of Diversity in Higher Education 1 (4): 39-168.

Walker, Alice. 1983. In Search of Our Mothers' Gardens: Womanist Prose. New York, NY: Harcourt Press.

Walker, Lee. 2019. "Rejection of a Manuscript and Career Resilience." PS: Political Science $\mathcal{E}$ Politics 52 (1): this issue. 